\title{
Integrated Quality Management Implementation Through Benchmarking
}

\author{
Anjar Agus Firawati \\ Department of Educational Administration \\ Universitas Negeri Malang, Indonesia \\ anjarfira@gmail.com
}

Asfi Mangzila

Department of Educational Administration

Universitas Negeri Malang, Indonesia

asfimangzila12@gmail.com

\author{
Anggraeni Cahyaningtyas \\ Department of Educational Administration \\ Universitas Negeri Malang, Indonesia \\ anggraenityas18@gmail.com \\ Quma Irah Larasati \\ Department of Educational Administration \\ Universitas Negeri Malang, Indonesia \\ qumairla7@gmail.com
}

\author{
Siti Munirotul Yuanita \\ Department of Educational Administration \\ Universitas Negeri Malang, Indonesia \\ munirotulyuanita@gmail.com
}

\begin{abstract}
This research aims to determine the implementation of integrated quality management in an educational institution. The collection of data is done by searching for a literature study that corresponds to the discussion to be conducted. The results of the research indicate some aspects that need to be considered in the implementation of integrated quality management in an educational institution, the first aspects of service, both aspects of human resources, three aspects of the environment, four aspects of the process, and fifth output/graduate aspects.
\end{abstract}

Keywords: management, quality, educational institutions, benchmarking

\section{INTRODUCTION}

Education is an effort to encourage a person to provide a learning experience in the form of formal, nonformal, and informal education that can be performed at school or outside school, During the human life to be implemented in his life. Currently, education in Indonesia is in dispute with the demands of the customer, the quality of an educational institution. Quality education is a customer's dream to get an education. Because they are aware of the present day, the competition lives increasingly higher. One is considered a high degree if it has a high educational background as well. He was also seen in his education [1].

The impact, many people who are willing to spend more costs to get an education with good quality. Based on community/customer needs it is educational institutions must continue to innovate to improve the quality of education through integrated quality management, which can be realized by the application of benchmarking to the educational institutions Considered better in its quality.

Benchmarking is a continuous and systematic process to compare institutional efficiencies in productivity size, quality, and practices with institutions and organizations that looks superior. By following all the developments that exist in the community, and the educational institution must continue to innovate to improve the quality of education. This quality education is a requirement and needs to be fulfilled by an educational institution. So at this time the institution is obliged to conduct quality management to make the education institution superior [2].

To perform the integrated quality management an educational institution can be benchmarked to other institutions of a kind that are better quality than the institution [3]. Integrated quality management is an effort to meet customers' needs at the lowest possible cost. Good institutions are institutions that continue to innovate and want to make changes to improve.

It should also be open to constructive inputs. The nonopen institution has been criticised and advised, and will not make any changes to be missed, the agency will stop at that level. During this time the technology also plays an important role, community want service is fast and easy, but quality. And every second technology found its latest findings. Therefore, good educational institutions that want to provide the best service to customers should want to innovate and change, one of which is with integrated quality management through benchmarking.

\section{METHOD}

This research uses research methods of literature studies or review literature. The study of literature [4] is a research activity conducted by reading various reference references such as books, journals, and other linear publications with researched subjects [5].

The purpose of literature studies: First, it is used as a reference material for paper making. Second, as a research reference material. So, the literature study used the authors/researchers to increase his insight according to the discussion conducted, namely in this discussion about the implementation of integrated quality management in an educational institution through benchmarking.

Several steps in the literature study, namely: (1) determining a topic that will be researched in an uncertain order so that it can be changed again, further focused on the research based on the chosen topic; (2) draft research and reference of literature to be used along with restrictions on contents and modifications; (3) look for references according to the research topic; and (4) write a literature 
review tailored to the selected reference source. Topics are compiled by developing a question that contains $5 \mathrm{~W}+1 \mathrm{H}$ (who, what, where, when, why, and how) [5].

\section{A. Service Aspect}

\section{RESULTS}

Based on the research [6] the mission of quality management of an educational institution is an effort to fulfil customers wishes. Services can be physical and nonphysical services. Good service will make the service provided by the education provider to its customers following the expectations of the customer so that customers feel satisfied.

A non-physical service is a service, such as giving teachers the knowledge of students. While physical services are the service that supports non-physical service processes, such as classrooms, library spaces, UKS space, and learning media [7]. Based on its satisfaction indicators of quality education services must be oriented to the needs of the customer or the recipient of the service.

\section{B. Aspects of Human Resources}

The human resource [8] is the source of all the power that comes from human beings that the organization can trade on. [6] The process of human resource recruitment so that schools can meet the expectations of the customer in the process of engineering must be done by the staff, namely HRD. Recruitment [9] is the process of collecting prospective officeholders following the plan of staff to occupy a specific position in the work function.

Recruitment is made based on submissions tailored to the needs of the educational institution. Meanwhile, in an effort to improve the quality of human resources in order to provide service that satisfies customers, the institution can do it in two ways, namely in a formal way that involves the existing human resources Education to pursue formal education in universities and in non-formal ways that involve human resources in activities such as training, teacher certification, workshops, and seminars.

\section{Environmental Aspects}

The environment [10] is covering all materials and stimulus inside and outside of individuals both physiological, psychological, and socio-cultural. Based on the research to create an atmosphere that can support the learning process is good, the school environment should be able to provide conducive conditions.

Customers should feel safe, comfortable, and peaceful, and the school must provide a beautiful and cool environment also school must also establish a good relationship between the school and the school residents including the community. To create a conducive atmosphere the school can provide facilities and infrastructure of the school and adapted to the education standards, where the ideal ratio compared to the number of students and their existence is adjusted to the needs of students.

\section{Process Aspects}

Based on the research [6] there are three steps teachers must take to do the learning, the first stage of learning planning. Before learning the teacher should do Planning learning from the authorization of the lesson documents by the principal, effective day analysis and effective lesson hours, semester programs, syllabus, RPP (implementation plan learning), the journal of learning associations, the attendance list, the list of values, the analysis of the evaluation results and its follow-up, grid of questions, key questions, scoring guidelines, and the calculation of the students final value.

Second, the stage of learning implementation, teachers must be able to perform a good learning process so that the objective of the lesson will be achieved to the fullest. In the implementation of this learning, there are opening activities, the teacher focuses the students to focus on the learning, further the core activities, teachers carry out the learning activities in accordance with the RPP that have been compiled. Next to the closing activity, the teacher can close and conclude the learning that has been done.

Hopefully in the process of implementing this learning students can get as much knowledge and according to their needs and wish. Lastly, that is the evaluation process, here the teacher must be able to assess or measure the description of the learning process that has been performed, whether it can be achieved by the students. Measurements can be seen from the three aspects of cognitive aspects, affective aspects and psychomotor aspects. The form of learning evaluation results in the form of a report. If the value in the report is less than the KKM (Minimal submission criteria) then the student must follow the remedial teaching and remedial test program.

\section{E. Aspect Output/Graduate}

The existence of the school can create a new generation because the previous has not been able to be able. Thus, with the existence of the student schools can have academic achievement in the form of access from the program and non-academic achievements obtained from programme extracurricular [6].

Besides, based on the results [11] research there are results of an analysis of influences between the quality of graduates and the motivation of work with the waiting period and the relevance of work is concluded that there is a significant influence between quality and work motivation against the waiting and relevance of work.

\section{A. Service Aspect}

\section{DISCUSSION}

Good and adequate physical and non-physical services will optimize the service provided by the institution to satisfy its customer's needs and expectations. Service provided must be prime, facilities and infrastructures are used to support the implementation of the provision of services to customers. The availability of mushola, canteen, laboratories, UKS, libraries, and others are some examples of the services provided by the school. This is following the opinion [12] states the services include: (1) room facilities, consisting of safe and orderly room service, information room, waiting room, prayer room, small room, and cafeteria, (2) public phones, and (3) the calling tool.

Based on such excellent service the end goal is to satisfy customers [13]. The size of satisfaction is the measure of success of the service is determined by the level of satisfaction of service recipients. Service recipient 
satisfaction is achieved when the recipient of service is obtained as needed and expected. So, it is necessary to do supervision on the implementation of the service, so that obtained results and known customer satisfaction level.

\section{B. Aspects of Human Resources}

The process of recruitment of human resources to meet customer needs and expectations in the process must be done by the staff of the part, namely HRD, which is based on filing tailored to the needs [14]. The recruitment and selection process begin when the recruiter identifies the needs of an institution's job vacancy through its HR planning and manager's request. This HR plan serves to demonstrate the needs of current and future vacancies. Also, recruitment is the search of employees of an institution that is needed by the institution [15].

Meanwhile, in an effort to improve the quality of human resources in order to provide services to satisfy customers, the school can do in two ways, which is a formal way to involve the existing human resources to attend education in Universities and non-formal ways of including human resources in training, teacher certification, workshops, and seminars.

Improvement of human resources, namely efforts to improve human quality by balancing material aspects and spiritual aspects. It is supported by the opinion [16] as human resources in carrying out its role as a member of the community as needed is to have the following characteristics: (1) Human beings who have an honest character, (2) human beings who have the skills and intelligent, (3) human beings who have the ability of entrepreneurship, and (4) people who have a competitive.

\section{Environmental Aspects}

To create an atmosphere that supports the learning process, the school environment should be able to provide a conducive atmosphere. Customers should also feel safe, comfortable, beautiful and cool environment with the existence of school greenery and the relationship between good and harmonious relationships between the school and the school residents including the community [16]. The learning environment is an outside condition, influence, and stimulation that includes physical, social, and intellectual influences that can affect the learning process.

To produce a conducive atmosphere the school can provide facilities and infrastructure following education standards, where the ratio is ideally suited to the number of students who exist and their existence according to the needs of students. Because it indirectly supports the process of learning to teach [18]. The existence of facilities and infrastructure in an educational institution is necessary for the educational process. Without educational facilities and infrastructure, the process of education will have serious difficulties, even can thwart education.

\section{Process Aspects}

In the learning process, there are three stages that teachers must do for learning, including learning planning. Before learning the teacher should do the learning plan from ratification of the lesson documents by the principal, effective day analysis and effective lesson hours, semester programs, syllabus, RPP, social journals Study, attendance list, List of values, analysis of evaluation and follow-up, grid of questions, key answers to questions, scoring guidelines, and the calculation of the student's final value. Planning is the activity done by arranging the steps to reach the goal. While learning is a guiding activity conducted by teachers to students to have a learning experience.

So learning planning is an activity to organize the learning steps that teachers do to influence learners to gain learning experience. Furthermore, [19] reveals the concept of learning planning to be seen from several points of view: (1) learning planning as a technology; (2) learning planning as a system; (3) learning planning as a discipline; (4) learning planning as a science; and (5) learning planning as a process.

Furthermore, a teacher must be able to perform a good learning process so that the learning objectives will be achieved optimally. In the implementation of this learning, there are opening activities, the teacher can focus the students on focusing on the learning done by the teacher, then the core activities, teachers can carry out the learning activities following the RPP that have been compiled. Next to the closing activity, the teacher can close and conclude the end of the learning that has been done.

Hopefully in the process of implementing this learning students can get as much knowledge and according to their needs and wish [20]. Teaching and learning activities are a condition that is deliberately created. The teacher who created it to teach the students. Teachers who teach and learn to students. With the combination of these two human elements, educative interaction is born by utilizing materials as a medium. All teaching components are optimally played to achieve the defined teaching objectives.

Last is the evaluation process, here teachers must be able to assess or measure the deliverable of the learning process that has been performed, whether or not it has been achieved by the students. Measurements can be seen from the three aspects of cognitive aspects, affective aspects and psychomotor aspects. The form of learning evaluation results is the value of the report. If the value of the report is less than the KKM then the student must follow the remedial teaching program and should follow the remedial test. [21] Evaluation capability is the ability to assess overall concepts related to values, outputs, effectiveness, feasibility, critical thinking, review and comparison of strategic, as well as the assessment related to internal criteria.

\section{E. Aspect Output/Graduate}

Schools can create new generations because before entering the school learners in a state of knowledge is still lacking, expected after admission at the school can have an academy achievement in the form of access from an interarticular program and Achievements obtained from extracurricular programs. [22] The goal is the final result to be achieved or output. Several factors affect the output, such as facilities, environment, resources, educators and so on.

\section{F. Benchmarking Implementation}

Concerning the five aspects above, school is expected to provide excellent services to customers, so that customers are satisfied because the needs and expectations can be fulfilled by the institution. After that, the school is 
expected to be a benchmarking that can be another referral school. Benchmarking is the process of measuring and comparing one institution with other best institutions to obtain information as a basic reference to improving the program [22].

Explained the process of benchmarking there are five stages, which is commonly referred to as benchmarking wheel. Consisting of: (1) plan, at this stage is measured on the implementation of the program, then compare with the school that will be used as a reference. (2) Search, at this stage find the institution that will be used as a reference repair or benchmarking. (3) Observe, at this stage, the school collects as much information about the successful tips of educational institutions that are used as benchmarks. (4) Analyze, at this stage analyzed observation result information to develop improvement program. (5) Adapt, at this stage is done drafting improvement program of the results of the analysis and subsequently implemented the school. In this stage also carried out supervision on the implementation of the program [22].

\section{CONCLUSION}

To meet the needs and expectations of customers in this time the school is obliged to implement quality management integrated with attention to several aspects of the service, aspect of human resources, environmental aspects, aspects of the process, and aspects of output / graduates with better educational institutions as a benchmarking step. Hopefully, later school can be a benchmarking for other schools.

For the advice in implementing the TQM school should be focused on customer demand, have a commitment to achieve the objectives, involving all the components in the school, measured the implementation of TQM through intensive oversight and continual improvement. It also pays attention to the benchmarking stages, ranging from plan, search, observe, analyze, and adapt. By implementing all the stages and considering the existing aspects of the school is expected to increase its quality to fulfil the wishes of customers.

\section{REFERENCES}

[1] Triwiyanto, T. 2015. Pengantar Pendidikan. Jakarta: PT Bumi Aksara.

[2] Karlof, B., \& Ostblom, S. 1997. Benchmarking: Petunjuk Menuju Keunggulan. Jogjakarta: Andi.

[3] Sriwidadi, T. 2001. Manajemen Mutu Terpadu. The Winners, 2(2). Retrieved July 13, 2019, from https://www.researchgate.net/publication/ 318986373_Manajemen_Mutu_Terpadu).

[4] Marzali, A. 2016. Menulis Kajian Literatur. Retrieved July 13, 2019, from https://www.researchgate.net.

[5] Berg, B. L., \& Howard, L. 2009. Qualitative Research Methods for the Social Sciences. Boston: Pearson.
[6] Husna, A. 2014. Penerapan Manajemen Mutu Terpadu dan Dampaknya di SD Budi Mulia Dua Sedayu Bantul. Retrieved July 13, 2019, from https://journal.uny.ac.id.

[7] Jaedun, A., \& Ishartiwi. 2008. Suvei Tingkat Kepuasaan Konsumen terhadap Kualitas Pelayanan Publik Bidang Pendidikan di Daerah Istimewa Yogyakarta. Yogyakarta: Universitas Negeri Yogyakarta.

[8] Murdiantari. 2017. Pengertian Sumber Daya Manusia. Retrieved July 13, 2019, from http://repository.umy.ac.id/bitstream/handle/123456789/7 860/BAB\%20II.pdf?sequence $=2 \&$ isAllowed $=y$.

[9] Yullyanti, E. 2009. Analisis Proses Rekrutmen dan Seleksi pada Kinerja Pegawai. Jurnal Ilmu Administrasi dan Organisasi, 16(3). Retrieved July 13, 2019, from http://journal.ui.ac.id/index.php/jbb/article/download/615/ 600 .

[10] Murti, D. I. 2012. Pengaruh Lingkungan Sekolah, Peran Guru dalam Proses Pembelajaran Terhadap Motivasi Belajar Siswa pada Mata Pelajaran Lokal Area Network di SMK Taman Siswa Jetis Yogyakarta. Retrieved July 13, 2019, from https://eprints.uny. ac.id/6630/.

[11] Lestari. 2015. Kualitas Lulusan, Motivasi, dan Pengaruhnya Terhadap Penempatan Kerja Alumni SMKN se-kota Malang. Retrieved July 13, 2019, from http://ap.fip.um.ac.id/wpcontent/uploads/2017/01/ARTIKEL.pdf.

[12] Moenir. H.A.S. 2008. Manajemen Pelayanan Umum di Indonesia. Jakarta: Bumi Aksara.

[13] Rahmayanty, N. 2013. Manajemen Layanan Prima. Yogyakarta: Graha Ilmu.

[14] Bellionardi, A.R.K. 2013. Model Analisis Perebutan dan Seleksi Karyawan di PT. Semarang Autocomp Manufacturing Indonesia (SAMI). Jurnal Ilmiah Dinamika Ekonomi dan Bisnis, 1(1). Retrieved July 13, 2019, from https://media.neliti.com.

[15] Timple, D. 2003. Memotivasi Pegawai. Jakarta: PT Elex Media Computindo.

[16] Djuwarijah. 2008. Penigkatan Kualitas Sumber Daya Manusia melalui Pendidikan Islam. Retrieved July 13, 2019, from https://media.neliti.com.

[17] Bloom, B. S. 1964. Stability and Change in Human Characteristics. New York: John Wiley Sons.

[18] Novita, M. 2017. Sarana dan Prasarana yang Baik Menjadi Bagian Ujung Tombak Keberhasilan Lembaga Pendidikan Islam. Nur El-islam, 4(2). Retrieved July 13, 2019, from https://media.neliti.com.

[19] Majid, A. 2011. Perencanaan Pembelajaran. Bandung: PT Remaja Rosdakarya.

[20] Gunarto. 2013. Model dan Metode Pembelajaran di Sekolah. Retrieved July 13, 2019, from https://www.research.unissula.ac.id.

[21] Nuriyah. N. 2014. Evaluasi Pembelajaran. Jurnal Edueksos, 3(1). Retrieved July 13, 2019, from https://syekhnurjati.ac.id.

[22] Munirah. 2015. Sistem Pendidikan di Indonesia: Antara Keinginan dan Realita. Auladunia, 2(2). http://journal.uinalauddin.ac.id).

[23] Paulus, M., \& Devie. 2013. Analisa Pengaruh Penggunaan Benchmarking terhadap Keunggulan Bersaing dan Kinerja Perusahaan. Business Accounting Review, 1(2). Retrieved July 13, 2019, from https://media.neliti.com. 